\title{
IMPLEMENTASI STRATEGI PEMASARAN DAN PENINGKATAN PELAYANAN JASA PENDIDIKAN DI SMP MUHAMMADIYAH 1 DEPOK YOGYAKARTA
}

\author{
Muhammad Iqbal \\ Sekolah Tinggi Agama Islam Negeri Teungku Dirundeng Meulaboh \\ Email: iqbaldarwismuhammad@staindirundeng.ac.id
}

\begin{abstract}
Abstrak
Penelitian ini dilakukan di SMP Muhammadiyah 1 Depok, ketika tahun 2009 SMP ini mengalami keterpurukan. Jika sekolah tidak mampu menerima anak-anak lebih dari 10 siswa maka SMP ini terancam akan ditutup. Faktor keterpurukan SMP ini disebabkan oleh marketing yang gagal dan pelayanan jasa pendidikan yang menurun. Dengan menerapkan implementasi strategi pemasaran jasa pendidikan, SMP Muhammadiyah 1 Depok ini mampu bangkit dari keterpurukan. Sehingga konsumen, orang tua, dan masyarakat kembali yakin dan percaya untuk menyekolahkan anaknya di SMP ini. Penelitian ini bertujuan untuk mengetahui implementasi strategi pemasaran jasa pendidikan dalam meningkatkan pelayanan pendidikan SMP Muhammadiyah 1 Depok Yogyakarta. Penelitian ini adalah penelitian kualitatif dengan menggunakan pendekatan teori strategi pemasaran jasa pendidikan. Data dikumpulkan melalui: (1) observasi, (2) dokumentasi, dan (3) wawancara mendalam kepada kepala sekolah, waka humas, waka kesiswaan, orang tua siswa dan siswa. Teknik validasi dan keabsahan data dengan triangulasi sumber dan triangulasi teknik. Hasil penelitian menunjukkan implementasi strategi pemasaran jasa pendidikan dalam meningkatkan pelayanan pendidikan SMP Muhammadiyah 1 Depok yaitu: (1) melakukan strategi pemilihan pasar dengan melakukan segmentasi pasar, targeting dan positioning. (2) menetapkan marketing mix dengan cara menerapkan produkproduk yang berkualitas dari SMP ini, menonjolkan letak geografisnya yang cukup strategis, menerapkan harga yang bersaing, dan juga melakukan langkah-langkah promosi serta langkah-langkah lainnya.
\end{abstract}

Kata Kunci: Implementasi Strategi Pemasaran, Pelayanan Pendidikan, Marketing mix.

\begin{abstract}
This research focused on SMP 1 Muhammadiyah Depok Sleman Yogyakarta, in 2009 this junior high school experienced adversity. If the school was unable to receive more than 10 students, this school would be closed. This SMP downturn is caused by failed marketing and declined educational services. By applied implementation the marketing strategy of educational services, SMP 1 Muhammadiyah Depok able to rise from adversity. So that consumers, parents and the community would trust and believe in sending their children to this junior high school. This study was aimed at determining the implementation of educational services marketing strategies in improving educational services in SMP 1 Muhammadiyah Depok Yogyakarta. This research was a qualitative research used the marketing strategy theory approach to
\end{abstract}


educational services. Data were collected through: (1) observation, (2) documentation, and (3) in-depth interviews with principals, public relations staff, student affairs, parents of students, and students. Data validation and validity techniques were undertaken by using source triangulation and technical triangulation. The results of the study indicated the implementation of marketing services marketing strategies in improving education services in SMP 1 Muhammadiyah Depok, namely: (1) implementing market selection strategies by segmenting the market, targeting and positioning. (2) establishing the marketing mix by applying quality products from this junior high school, highlighting its geographical location that is quite strategic, applying competitive prices, and also taking promotional steps and other steps.

Keywords: Marketing Strategy Implementation, Educational Services, Marketing mix.

\section{PENDAHULUAN}

Mulai saat ini pendidikan dipahami sebagai sebuah corporate, yang artinya suatu lembaga pendidikan disebut sebagai organisasi produksi yang menghasilkan jasa pendidikan yang dapat dibeli oleh para konsumen. ${ }^{1}$ Dalam hal ini, lembaga pendidikan dipahami sebagai lembaga yang memberikan layanan jasa pendidikan kepada siswa, mahasiswa, ataupun masyarakat umum. Oleh karena itu, pihak sekolah harus meningkatkan kualitas dan mengembangkan implementasi strategi pemasarannya agar mutu lembaga pendidikannya semakin meningkat dan dapat menarik banyak pendidik maupun siswa. Karena, prosedur pemasaran dalam dunia pendidikan yang baik adalah memberikan mutu layanan intelektual dan membentuk watak/sikap secara menyeluruh. ${ }^{2}$

Pendidikan dipercaya sebagai suatu alat dan strategi untuk meningkatkan taraf hidup manusia. Melalui pendidikan, manusia menjadi berfikir, memiliki perilaku yang sopan, memiliki kemampuan (skill), sikap dan tindakan hidup yang baik, sehingga setiap elemen individual dapat bergaul secara baik di masyarakat. Pendidikan menjadi investasi ke depan (future) yang mampu memberikan keuntungan bagi sosial dan pribadi sehingga menjadikan bangsa bermartabat dan individu manusia yang memiliki derajat. ${ }^{3}$ Hal tersebut telah terbukti dengan proses pendidikan yang terus melakukan inovasi dari masa ke masa, sesuai dengan perkembangan global dan kemampuan sumber daya manusia itu sendiri, sehingga pendidikan terus mengalami kemajuan yang sangat pesat. Hal ini terbukti dengan adanya penemuan-penemuan ilmu pengetahuan yang baru dan ini menunjukkan

${ }^{1}$ Buchari Alma, Manajemen Corporate \& Pemasaran Jasa Pendidikan (Bandung: Alfabeta, 2008), hlm. 13.

${ }^{2}$ Ara Hidayat and Imam Machali, Pengelolaan Pendidikan, Konsep, Prinsip, Dan Aplikasi Dalam Mengelola Sekolah Dan Madrasah (Yogyakarta: Penerbit Kaukaba, 2012), hlm. 229.

${ }^{3}$ Engkoswra \& Komariah, Administrasi Pendidikan (Bandung: Alfabeta, 2010), hlm. 1. 
bahwa pendidikan selalu memiliki sifat maju dan berorientasi ke depan (future oriented). ${ }^{4}$

Pada zaman sekarang minat masyarakat untuk melanjutkan pendidikan sekolah sangatlah meningkat. Ini terbukti dengan banyaknya instansi-instansi dan lembaga yang mendirikan sekolah boarding school, sekolah IT (Islam Terpadu) terutama dalam persaingan untuk memiliki kualitas yang unggul. Dunia pendidikan di Indonesia antara satu lembaga memiliki persaingan dengan lembaga lainnya yang sangat tajam dan luar biasa, sehingga lembaga pendidikan dituntut untuk terus melakukan inovasi perubahan pemasaran jasa pendidikan sehingga mampu untuk mengikuti kompetisi. Setiap lembaga pendidikan harus memiliki keunggulan tersendiri dalam memasarkan lembaga pendidikannya agar sumber daya manusia dan mutu dalam lembaga itu bisa bertahan, sehingga setiap lembaga pendidikan memerlukan strategi pemasaran jasa pendidikan agar sekolah mampu bertahan dan terus berkembang. ${ }^{5}$

Persaingan antar lembaga pendidikan semakin ketat, hal ini terlihat jelas dari munculnya berbagai lembaga pendidikan yang menawarkan produk dan keunggulannya masing-masing sehingga pemasaran untuk lembaga pendidikan mutlak diperlukan. Sekolah ataupun lembaga pendidikan perlu belajar dan memiliki kesadaran dalam meningkatkan kepuasan pelanggan siswanya sebagai sebuah lembaga penyedia jasa yang merupakan suatu proses yang berkelanjutan. Untuk memenangkan kompetensi antar lembaga pendidikan maka setiap lembaga pendidikan diharuskan untuk memiliki strategi dalam memasarkan jasa pendidikannya.

Lembaga pendidikan harus bisa merancang strategi yang tepat dalam menarik konsumen, karena itu lembaga pendidikan harus bisa meninggalkan paradigma dan cara-cara lama agar lembaga pendidikan/sekolah tidak dianggap oleh masyarakat dan pemerintah hanya sebatas lembaga sosial semata. Dengan demikian, mutu dan kualitas suatu lembaga pendidikan harus selalu dipertahankan dan ditingkatkan serta selalu menjaga kredibilitasnya sehingga lembaga pendidikan akan mendapatkan pengakuan dari stakeholder.

Marketing jasa pendidikan yaitu aktivitas lembaga pendidikan dalam memberi dan menyampaikan jasa pendidikan kepada stakeholder dengan cara yang baik. Pada saat penerimaan siswa baru tiap tahun muncul iklan-iklan dari perguruan tinggi swasta, di dalam sosial media, radio, selebaran cetak, brosur dan spanduk di pinggir jalan dan dikampus. Semua ini bertujuan untuk menarik perhatian calon pendidik baru dan ini merupakan gejala marketing dalam tingkat permulaan. Etika marketing memang sangat menghindari karakter yang tidak baik, dan selalu

\footnotetext{
${ }^{4}$ Hamruni, Edutainment Dalam Pendidikan Islam dan Teori-Teori pembelajaran Quantum (Yogyakarta: Fakultas Tarbiyah UIN Sunan Kalijaga, 2009), hlm. 1

${ }^{5}$ Fandy Tjiptono, Pemasaran Jasa (Yogyakarta: Penerbit Andi, 2014), hlm. 39.
} 
mengharapkan lembaga pendidikan menawarkan mutu layanan intelektual dan pembentukan karakter secara menyeluruh. ${ }^{6}$

Lembaga pendidikan adalah sebuah organisasi produksi yang menghasilkan jasa pendidikan dan dibeli oleh para stakeholder, hal ini jika kita melihat dari kacamata sebuah corporate. Stakeholder disini adalah para pelajar, siswa, dan mahasiswa. Apabila lembaga pendidikan tidak bisa memasarkan produknya, dalam hal ini dikarenakan mutu yang tidak disukai oleh stakeholder, tidak dapat menambah wawasan dan nilai karakter pribadi individu, maka produk jasa yang ditawarkan tidak akan berhasil. Sehingga akibatnya sekolah maupun perguruan tinggi terpaksa harus ditutup. ${ }^{7}$ Disini pengelola lembaga pendidikan Islam dituntut untuk mampu memenuhi standar sebagai lembaga pendidikan yang layak dalam menyelenggarakan kegiatan pendidikan, pembelajaran, dan pengajaran, sehingga penataan ini dipahami sebagai suatu bentuk konsistensi dalam peningkatan kualitas mutu pendidikan. ${ }^{8}$

Kepuasan pelanggan jasa pendidikan menjadi penentu faktor keberhasilan di dalam kompetisi pendidikan seperti sekarang ini. Apabila lembaga pendidikan tidak dapat memberikan kualitas yang baik, maka stakeholder tidak akan menggunakan jasa yang ditawarkan. Sebaliknya jika produk yang ditawarkan secara sama namun harga yang lebih murah maka stakeholder akan pergi ke tempat yang lebih murah. Jika lembaga menghasilkan produk jasa pendidikan yang tidak diinginkan sama sekali oleh stakeholder maka dalam kurun waktu yang tidak terlalu lama lembaga akan gulung tikar. Hanya lembaga yang bisa memenuhi kualifikasi kebutuhan stakeholder yang akan mampu untuk bertahan. ${ }^{9}$

Mulai dari layanan dalam bentuk fisik bangunan sampai kepada layanan berbagai fasilitas merupakan layanan sebuah lembaga pendidikan. Stakeholder akan selalu menuntut untuk mendapatkan pelayanan terbaik dari pengelola jasa pendidikan. Stakeholder akan memperhatikan seluruh fasilitas yang dimiliki oleh lembaga penyedia jasa pendidikan, seperti ruangan belajar, perpustkaan, masjid, ruangan laboratorium dan lain sebagainya. ${ }^{10}$

Lembaga pendidikan membutuhkan pemimpin dan karyawan yang mempunyai mutu dan kualitas dalam menciptakan produk yang unggul secara berkelanjutan. Memberikan pelayanan prima kepada stakeholder merupakan langkah awal suatu lembaga pendidikan untuk mampu bersaing. Dikarenakan keinginan stakeholder adalah proses yang terus dan selalu berubah-ubah, sehingga lembaga

${ }^{6}$ Buchori Alma \& Ratih hurriyati, Manajemen Corporate Strategi \& Pemasaran Jasa Pendidikan (Bandung: Alfabeta, 2008), hlm. 30.

${ }^{7}$ Ibid, hlm. 13.

${ }^{8}$ Ali Nizar dan Ali Syatibi, Manajemen Pendidikan Islam, (Bekasi: Pustaka Isfahan, 2009), hlm. 191.

${ }^{9}$ Rambat Lupiyoadi \& A.Hamdani, Manajemen Pemasaran Jasa (Jakarta: Salemba Empat, 2006), hlm. 87.

10 Atep Adya Barata, Dasar-Dasar Pelayanan Prima (Jakarta: Elex Media Kompetido, 2003), hlm. 56. 
pendidikan harus selalu memberikan pelayanan secara berkesinambungan dan terusmenerus dalam mengembangkan pelayanan sesuai dengan kebutuhan zaman. ${ }^{11}$

Pemimpin yang ada di lembaga pendidikan harus mampu dalam mengembangkan inovasi, kompetensi dan mampu menjadi agen perubahan bagi yang lain. Lembaga pendidikan Islam membutuhkan pemimpin yang mampu membentuk visi dan misi dalam kerja nyatanya, sehingga siap dalam persaingan menuju lembaga yang berkelas dunia. Seluruh kegiatan yang dilakukan oleh lembaga pendidikan akhirnya bertujuan untuk memberikan nilai kepada pelanggan jasa pendidikan sesuai dengan keinginan dan mampu membuat pelanggan jasa pendidikan senang serta terpenuhi seluruh keinginannya. ${ }^{12}$

SMP Muhammadiyah 1 Depok Yogyakarta berdiri mulai sejak 1 Januari 1968. Sejak berdirinya hingga saat ini banyak hal yang dialami yaitu pasang surut kemajuan. Mulai pada awal era perjuangan di tahun 1968-1980, era berjayanya di tahun 1980-1994 (puncaknya pada tahun 1985 siswanya hingga 596 siswa), sampai kepada era keterpurukan di tahun 1994-2008. Tahun 2008 sekolah ini tersisa kelas VII-nya hanya 8 siswa. Namun di Era berikutnya tahun 2009 - saat ini memiliki 326 siswa. Pengalaman terbaik ini yang mampu bangkit pada era kebangkitan dan kemajuan SMP Muhammadiyah 1 Depok Sleman di tahun 2009 hingga saat ini. Dimana Bapak Abdullah Mukhti S.Pd.I diangkat menjadi Kepala Sekolah SMP Muhammadiyah 1 Depok sejak tahun 2009 hingga saat ini. ${ }^{13}$

SMP Muhammadiyah 1 Depok Yogyakarta dahulu dikenal sebagai SMP Muhammadiyah Stan karena berada di daerah Stan Maguwoharjo Depok. SMP ini memiliki prestasi akademik maupun non akademik (terutama di bidang olahraga). Sejak Kepala Sekolah pertama dan salah satu pendiri SMP ini meninggal SMP ini kian lama semakin meredup dan menurun peminat para peserta didiknya hingga puncak keterpurukan terjadi pada tahun ajaran 2008/2009 kelas VII nya yaitu hanya berjumlah 8 siswa. ${ }^{14}$

Proses keterpurukan SMP ini yang pertama disebabkan oleh marketing yang gagal, dan salah satu inti dari marketing adalah implementasi strategi pemasaran jasa pendidikan. ${ }^{15}$ Proses keterpurukan selanjutnya dikarenakan pelayanan jasa pendidikan SMP Muhammadiyah 1 Depok Sleman yang menurun. Hal ini disebabkan karena pelayanan jasa pendidikan yang tidak berorientasi dan memenuhi kepentingan pelanggan jasa pendidikan sehingga pelanggan jasa pendidikan tidak dapat menerima pelayanan prima yang terbaik dan optimal. ${ }^{16}$

11 Muhaimin, Manajemen Pendidikan (Aplikasinya dalam Penyusunan Rencana Pengembangan Sekolah/Madrasah), (Jakarta: Kencana prenada Media Group, 2009), hlm. 98.

${ }^{12}$ David Wijaya, Pemasaran Jasa Pendidikan (Jakarta: Salemba Empat 2012), hlm. 74.

${ }^{13}$ Observasi lapangan di SMP Muhammadiyah 1 Depok pada tanggal 21 Mei 2018.

${ }^{14}$ Ibid.

${ }^{15}$ Pertemuan Seminar dengan Nara Sumber Bapak Abdullah Mukti di SMP Muhammadiyah 1 Depok Sleman pada tanggal 21 Mei 2018 pukul 15.30 WIB.

${ }^{16}$ Pertemuan Seminar dengan Nara Sumber Bapak Abdullah Mukti di SMP Muhammadiyah 1 Depok Sleman pada tanggal 21 Mei 2018 pukul 15.30 WIB. 


\section{LANDASAN TEORI}

\section{Strategi Pemasaran Jasa Pendidikan}

Istilah strategi berasal dari kata Yunani strategia $($ stratos $=$ militer, dan agesislao $=$ memimpin), yang artinya seni atau ilmu untuk menjadi seorang jenderal. Konsep ini memang sesuai dan relevan dengan situasi pada zaman dulu yang sering diwarnai terjadinya perang, sosok seorang jenderal dibutuhkan untuk memimpin suatu angkatan militer perang agar dapat memenangkan suatu peperangan. Selanjutnya konsep strategi militer pun diadaptasi ke dalam dunia bisnis. ${ }^{17}$

Fandy Tjiptono mengemukakan bahwa strategi merupakan program untuk mendesain agar suatu organisasi mampu mengembangkan dan mengimplementasikan misinya. Strategi juga dapat disebut sebagai respon terhadap organisasi yang terjadi di sekitar lingkungannya. ${ }^{18}$ Berdasarkan teori di atas maka dapat disimpulkan bahwa strategi merupakan langkah organisasi yang diterapkan dalam suatu kebijakan yang telah disusun agar tercapai suatu keinginan yang ditetapkan.

Menurut Ara Hidayat dan Imam Machali, pemasaran adalah suatu proses yang terjadi pada suatu organisasi secara sosial dengan pihak lain sehingga terjadinya pertukaran baik dengan individu maupun kelompok yang didalamnya terdapat keinginan dan kebutuhan yang ingin didapatkan. ${ }^{19}$ Cannon, Perreault, McCarthy mendefinisikan pemasaran sebagai suatu aktivitas dimana produsen memenuhi kebutuhan pelanggan baik dalam barang maupun jasa. ${ }^{20}$

Berdasarkan dari pengertian di atas Ara Hidayat dan Imam Machali menekankan proses pertukaran terjadi ketika keinginan dan kebutuhan individu dan kelompok dapat dipenuhi. Sedangkan menurut Cannon dan kawan-kawan yang dimaksud pemasaran yaitu konsumen dapat menerima kebutuhannya baik itu barang atau jasa melalui pendistribusian. Menurut Lockhart pemasaran jasa pendidikan adalah strategi dalam melakukan sesuatu hal yang berfokus kepada orientasi sekolah di mana siswa, orang tua siswa dan karyawan telah merasa dan menganggap sekolah sebagai suatu lembaga atau institusi yang mampu mendukung masyarakat berdedikassi dalam melayani kebutuhan dan keinginan pelanggan jasa pendidikan. ${ }^{21}$

Marketing jasa pendidikan berarti aktivitas yang memuaskan dari lembaga pendidikan dalam memberikan layanan atau menyampaikan jasa pendidikan kepada

\footnotetext{
${ }^{17}$ Fandy Tjiptono, Strategi Pemasaran, (Yogyakarta: Andi, 1997), hlm. 3.

${ }^{18}$ Ibid.

${ }^{19}$ Ara Hidayat Dan Imam Machali, Pengelolaan Pendidikan, (Yogyakarta: Kaukaba, 2012),
} hlm. 223.

${ }^{20}$ Cannon, Perreault, McCarthy, Pemasaran Dasar Pendekatan Manajerial Global, (terj.) oleh. Diana Angelica, (Jakarta: Salemba 4, 2008), hlm. 8.

${ }^{21}$ David Wijaya, Pemasaran Jasa..., hlm. 16. 
pelanggan pendidikan. $^{22}$ Menurut Kotler dan Fox dalam David Wijaya mengemukakan defenisi pemasaran dalam sekolah berfokus kepada tujuan sekolah, dimulai dari analisis, planing, pelaksanaan dan pengendalian program yang telah dirumuskan secara bersama secara hati-hati. Sehingga mampu menghasilkan pertukaran nilai secara suka rela dengan pasar target (target market). ${ }^{23}$

Kotler mengartikan jasa sebagai " a service is any act or performance that one party can offer to another that is essentially intangible and does not result in the ownership of anything. Its production may or may not be tied to a physical Product." 24 Maksudnya jasa merupakan setiap kinerja yang disampaikan oleh satu pihak kepada pihak yang lain secara prinsip tidak berwujud dan tidak menyebabkan kepindahan kepemilikan.

Kotler dan Fox mendefinisikan tujuan utama pemasaran jasa pendidikan adalah "pertama memenuhi visi dan misi lembaga pendidikan dengan tingkat keberhasilan yang besar, kedua meningkatkan kepuasan pelanggan jasa pendidikan, ketiga meningkatkan ketertarikan terhadap sumber daya pendidikan dan keempat meningkatkan efisiensi pada aktivitas pemasaran jasa pendidikan." 25

Berdasarkan pengertian di atas maka dapat disimpulkan bahwa pemasaran jasa pendidikan merupakan suatu aktivitas penawaran, pertukaran dimana siswa, orang tua siswa dan stakeholder dapat merasakan pelayanan yang dilakukan dan diberikan oleh lembaga pendidikan setelah pelanggan jasa pendidikan membeli jasa dari lembaga pendidikan tersebut. Layanan yang diberikan berupa mutu yang bagus dan berkualitas, guru yang mampu dan profesional, sarana prasarana yang cukup dan memadai, serta lingkungan yang nyaman dan kondunsif. Dengan pelayanan yang demikian, pihak pelanggan akan senang dan dapat terpuaskan.

\section{Tiga Unsur Pemasaran}

Di dalam keberhasilan suatu proses pemasaran, adanya unsur-unsur yang dapat membantu dalam berhasilnya suatu proses pemasaran. Terdapat tiga unsur utama dalam pemasaran, yaitu: segmentasi pasar, targetting dan positioning. ${ }^{26}$

Tiga unsur pemasaran dalam Islam juga dilakukan oleh Muhammad Arham dengan konsep pemasaran konvensional. Arham menawarkan strategi pemasaran Islam menggunakan pendekatan historis yang ada dalam Islam serta

22 Buchari Alma, Manajemen Corporate dan Strategi Pemasaran Jasa Pendidikan, (Bandung: Alfabeta, 2008), hlm. 31.

${ }^{23}$ David Wijaya, Pemasaran Jasa..., hlm. 16.

${ }^{24}$ Ara Hidayat dan Imam Machali, Pengelolaan Pendidikan, Konsep, Prinsip, Dan Aplikasi Dalam Mengelola Sekolah Dan Madrasah (Yogyakarta: Penerbit Kaukaba, 2012), hlm. 228.

25 Philip Kotler, Manajemen pemasaran: analisis, perencanaan, implementasi, dan pengendalian Jilid 2 Edisi 8, (terj.) oleh. A.B. Susanto, (Jakarta: Salemba Empat, 1995), hlm. 167.

${ }^{26}$ Ara Hidayat dan Imam Machali, Pengelolaan Pendidikan, Konsep, Prinsip, Dan Aplikasi Dalam Mengelola Sekolah Dan Madrasah (Yogyakarta: Penerbit Kaukaba, 2012), hlm. 224-225. 
mengintegrasikannya dengan teori-teori strategi pemasaran yang dimiliki oleh Philip Kotler. $^{27}$

1. Segmentasi Pasar, yaitu suatu kegiatan memilih dan memilah serta mengelompokkan jenis konsumen secara berbeda-beda dan terpisah. Konsumen ini masing-masing memiliki karateristik, keinginan dan kebutuhan produk, serta bauran pemasarannya secara tersendiri. ${ }^{28}$ Segmentasi pasar ini memang sangat penting dilakukan untuk mengetahui tujuan dan sasaran konsumen yang akan dimasuki. Arham memberikan contoh seperti Rasulullah Saw. ketika beliau masih menjadi seorang pedagang yang membuat segmentasi pasar secara cerdas. Pengetahuan yang dimiliki Rasulullah Saw. adalah beliau mengetahui bagaimana karakteristik kehidupan orang-orang Bahrain, beliau juga mengetahui hal yang biasa dan suka dimakan dan diminum oleh masyarakat Bahrain. ${ }^{29}$

2. Targetting, yaitu kegiatan dalam memilih satu, dua atau lebih segmen pasar yang menjadi target untuk dimasuki. ${ }^{30}$ Setelah melakukan segmentasi pasar, seorang pemasar harus bisa menemukan diantara beragamnya segmen pasar yang telah dimasuki yang menjadi pasar paling potensial dalam memasarkan usahanya. Rasulullah Saw. merupakan orang yang memiliki insting yang cerdas, sebagaimana dalam ilmu pemasaran konvensional dikenal dengan istilah difirentiated marketing, Rasulullah Saw. mampu melakukan inovasi produk sehingga berbeda dengan yang lain dan membuat masyarakat menjadi tertarik dengan usaha yang beliau pasarkan. ${ }^{31}$

3. Positioning, yaitu menetapkan dimana posisi pasar pemasar, hal ini dilakukan untuk mempertinggi nilai produk dan memberikan informasi tentang keunggulan produk yang dimiliki kepada para konsumen dan pelanggan. ${ }^{32}$ Langkah seperti ini juga telah dilakukan oleh Rasulullah Saw. ketika beliau memasarkan barang dagangannya. Beliau mampu dalam merebut hati dan membuat para konsumen serta pelanggannya menjadi senang karena sifatnya yang mulia, amanah, jujur dan terpercaya. ${ }^{33}$

${ }^{27}$ Muhammad Arham, "Islamic Perspective on Marketing”, Journal of Islamic Marketing, vol. 1, no. 2. (2010), hlm. 149-164.

${ }^{28}$ Ara Hidayat dan Imam Machali, Pengelolaan Pendidikan, Konsep, Prinsip, Dan Aplikasi Dalam Mengelola Sekolah Dan Madrasah (Yogyakarta: Penerbit Kaukaba, 2012), hlm. 224-225.

29 Gerard J. Tellis, et. al., "Radical Innovation Across Nations: The Preeminence of Corporate Culture", Journal of Marketing, vol. 73 (2009), hlm. 3-23.

${ }^{30}$ Ara Hidayat dan Imam Machali, Pengelolaan Pendidikan, Konsep, Prinsip, Dan Aplikasi Dalam Mengelola Sekolah Dan Madrasah (Yogyakarta: Penerbit Kaukaba, 2012), hlm. 224-225.

31 Gerard J. Tellis, et. al., "Radical Innovation Across Nations: The Preeminence of Corporate Culture", Journal of Marketing, vol. 73 (2009), hlm. 3-23.

${ }^{32}$ Ara Hidayat dan Imam Machali, Pengelolaan Pendidikan, Konsep, Prinsip, Dan Aplikasi Dalam Mengelola Sekolah Dan Madrasah (Yogyakarta: Penerbit Kaukaba, 2012), hlm. 224-225.

33 Gerard J. Tellis, et. al., "Radical Innovation Across Nations: The Preeminence of Corporate Culture", Journal of Marketing, vol. 73 (2009), hlm. 3-23. 


\section{Bauran Pemasaran (Marketing Mix)}

Pada proses perkembangannya, penggunaan istilah marketing sudah digunakan dalam segala aktivitas manusia, bukan hanya digunakan oleh lembaga atau organisasi yang berbau profit saja, tetapi pada saat ini juga sudah digunakan oleh lembaga atau organisasi yang merupakan non profit.

Hal ini sebagaimana yang telah diungkapkan oleh Morris dikutip oleh Muhaimin, untuk keaadaan saat ini baik lembaga dan organisasi yang berbau profit maupun tidak maka tetap dan tidak bisa terlepas dari yang namanya pemasaran (marketing), karena lembaga dan organisasi bisa memilih untuk melakukan pemasaran dengan sebaik mungkin demi kemajuan sebuah lembaganya ataupun tidak memperhatikan pemasaran secara baik demi kehancuran sebuah lembaganya. Pada zaman modern saat ini pun pendidikan juga mengambil dan menggunakan istilah pemasaran (marketing) dalam melakukan pemasaran sekolahnya dengan menonjolkan jasa pendidikan yang dimiliki. Agar terbentuknya citra baik sekolah kepada khalayak ramai maupun masyarakat maka disini dibutuhkannya upaya dalam melakukan pemasaran yang sekarang dikenal dengan istilah strategi bauran pemasaran. ${ }^{34}$

Menurut Kotler dikutip Wijaya bauran pemasaran merupakan pokok-pokok dan serangkaian unsur pemasaran yang bisa dikontrol dan dikendalikan oleh sebuah lembaga yang mana adanya usaha memadukan dan mencampur seluruh kompenen yang ada di dalamnya agar tercapai tujuan dalam target maupun pasar sasaran. Komponen-komponen atau unsur-unsur yang ada di dalam bauran pemasaran memiliki tujuh karakteristik yang disingkat menjadi $7 \mathrm{P}^{35}$

Dalam pemasaran Islam Nurhazirah Hashim dan Muhammad Iskandar Hamzah juga telah melakukan dan mengintegrasikan konsep pemasaran 7P's kedalam ajaran Islam (Islamic teaching). 7P's yang dimaksud disini adalah 7 unsur dan elemen bauran pemasaran, yaitu product, price, place, promotion, people, physical evidence, dan process. Ketujuh unsur dan elemen bauran pemasaran ini kemudian diintegrasikan kepada 7P's Islam yang dikenalkan oleh Wilson J. A. J. (2012), yaitu pragmatism, palliation, patience, pertinence, peer-support, pedagogy dan persistence. ${ }^{36}$

34 Muhaimin, Manajemen Pendidikan (Aplikasinya dalam Penyusunan Rencana Pengembangan Sekolah/Madrasah),cet.4 (Jakarta: Kencana prenada Media Group, 2012), hlm. 54.

${ }^{35}$ David Wijaya, Pemasaran Jasa Pendidikan: Mengapa Sekolah Memerlukan Marketing? (Jakarta: Salemba Empat, 2012), hlm. 170.

${ }^{36}$ Wilson, J. A. J. (2012), "Looking at Islamic marketing, branding and Muslim consumer behavior beyond the 7P's", Journal of Islamic Marketing, Vol. 3, hlm. 212-216. 


\section{Pelayanan Pendidikan}

Bagi perkembangan suatu bangsa harapan yang sangat besar diletakkan kepada pelajar dan peserta didik. Pendidikan harus selalu melakukan inovasi dan menciptakan kualitas yang bermutu agar generasi bangsa dapat terus maju sehingga mampu dalam menghadapi masa depan yang penuh tantangan. Di dalam pendidikan pelajar dan peserta didik bukan hanya sekedar diajarkan bagaimana menjadi pelajar yang gemar membaca, memiliki ilmu pengetahuan yang luas, tetapi harus lebih jauh dari pada itu. Pelajar dan peserta didik harus mampu mengimplementasikan ilmu yang telah di dapat dari hasil bacaannya untuk memecahkan masalah dan mengambil keputusan yang tepat dalam sosial dan masyarakat, dan yang terpenting adalah mereka mampu dan cepat dalam merebut informasi.

Pelayanan jasa pendidikan memiliki ciri khas khusus dan karakteristik dasar yang mencakup kepada tiga aspek, yaitu standar jasa pendidikan memiliki sifat yang baku, jasa pendidikan memiliki sifat istimewa dan memberikan keinginan serta kepuasan yang memungkinkan memberikan harapan kepada para pelanggan jasa pendidikan.

Ada tiga dimensi jasa pendidikan yang bermutu dan berkualitas yang bisa dilakukan, yang pertama kualitas teknis jasa pendidikan sebagaimana yang berkaitan dengan hasil jasa pendidikan, kedua kualitas yang dimiliki oleh pemberi dan fungsional jasa pendidikan kepada pelanggan jasa pendidikan, dan ketiga adanya reputasi yang dimiliki oleh penyedia jasa pendidikan. ${ }^{37}$ Keberhasilan dalam membangun, mengembangkan dan melaksanakan pelayanan pendidikan tidak terlepas dari kemampuan suatu lembaga dalam memilih pendekatannya. Barata telah membangun, mengembangkan dan melaksanakan pola pelayanan pendidikan berdasarkan konsep 3A, yaitu:

1. Attitude (sikap): pelayanan jasa pendidikan menurut konsep sikap meliputi tiga hal yaitu yang pertama dapat memberikan layanan dan melayani pelanggan jasa pendidikan berdasarkan penampilan yang sopan dan menarik, kedua dapat melayani pelanggan jasa pendidikan dengan cara berpikir positif dan sehat, dan ketiga memberikan layanan kepada pelanggan jasa pendidikan dengan tindakan dan sikap menghargai,

2. Attention (perhatian): pelayanan prima yang dapat diberikan jasa pendidikan menurut konsep perhatian meliputi tiga hal yaitu yang pertama mendengarkan keinginan dan memahami kebutuhan pelanggan jasa pendidikan secara baik dan sungguh-sungguh, kedua melihat dan menghargai setiap perilaku dari pelanggan jasa pendidikan, dan ketiga memberikan perhatian semaksimal mungkin kepada pelanggan jasa pendidikan, dan

${ }^{37}$ David Wijaya, Pemasaran Jasa Pendidikan: Mengapa Sekolah Memerlukan Marketing? (Jakarta: Salemba Empat, 2012), hlm. 257. 
3. Action (tindakan): pelayanan prima yang dapat diberikan jasa pendidikan berdasarkan konsep tindakan meliputi lima hal yaitu yang pertama mencatat setiap pesanan yang diinginkan dari pelanggan dan konsumen jasa pendidikan, yang kedua mencatat keinginan dan kebutuhan yang diinginkan pelanggan dan konsumen jasa pendidikan, yang ketiga mengulang dan menegaskan kembali kebutuhan yang diinginkan pelanggan jasa pendidikan, yang keempat memberikan dan mewujudkan kebutuhan yang diinginkan pelanggan jasa pendidikan, dan yang kelima menyatakan ucapan terimakasih secara senang dengan harapan pelanggan jasa pendidikan ingin kembali membeli dan menikmati produk jasa pendidikan yang diberikan. ${ }^{38}$

\section{METODOLOGI PENELITIAN}

Penelitian ini merupakan penelitian kualitatif, yaitu dengan cara menggunakan pendekatan investigasi karena disini peneliti mengumpulkan data dengan strategi bertatap muka secara langsung dan berinteraksi dengan orang-orang ditempat penelitian. ${ }^{39}$ Dalam teknik penentuan subyek, peneliti disini menggunakan cara dan teknik purposive sampling dan snowball sampling. Menurut Sugiyono purposive sampling merupakan teknik pengambilan sampel suatu sumber data dengan mempertimbangkan segala sesuatu. Pertimbangan ini misalnya orang tersebut dianggap paling mengetahui tentang sesuatu fakta yang kita harapkan, atau bisa jadi dia adalah sebagai pemimpin yang dapat berkuasa sehingga akan memudahkan peneliti dalam mencari dan mengamati obyek dan situasi sosial yang ada di lapangan. ${ }^{40}$

Berdasarkan uraian di atas, subyek penelitian dengan teknik purposive sampling adalah peneliti sudah mengetahui siapa saja sumber data yang akan diwawancarai. Peneliti memilih narasumber yang benar-benar mengetahui, memahami, dan mengalami kejadian yang akan diteliti. Sedangkan teknik snowball sampling adalah cara dan teknik pengumpulan data dari sumber data di lapangan yang mula-mula jumlahnya tidak banyak, dan lama-lama sumber data ini menjadi banyak. ${ }^{41}$ Hal ini disebabkan data yang didapatkan dirasa belum cukup. Data dikumpulkan melalui: (1) observasi, (2) dokumentasi, dan (3) wawancara mendalam kepada kepala sekolah, waka humas, waka kesiswaan, orang tua siswa dan siswa. Teknik validasi dan keabsahan data dengan triangulasi sumber dan triangulasi teknik.

38 Atep Adya Barata, Dasar-Dasar Pelayanan Prima (Jakarta: Elex Media Kompetido, 2003), hlm. 58.

${ }^{39}$ Syamsuddin \& Vismania, Metode Penelitian Pendidikan Bahasa (Bandung : PT. Remaja Rosdakarya, 2007), hlm. 74.

${ }^{40}$ Sugiono, Metode Penelitian Kuantitatif, Kualitatif dan R\&D (Bandung: Alfabeta, 2013), hlm. 218-219.

${ }^{41}$ Sugiyono, Metode Penelitian Pendidikan, (Bandung: Alfabeta, 2012), hlm. 15 


\section{HASIL DAN PEMBAHASAN}

Dari hasil penelitian tentang Implementasi Strategi Pemasaran Jasa Pendidikan SMP Muhammadiyah 1 Depok Yogyakarta dengan Menerapkan Segmentasi Pasar, Targeting dan Positioning dapat diuraikan sebagai berikut:

\section{Segmentasi pasar}

Segmentasi pasar yaitu suatu kegiatan memilih dan memilah serta mengelompokkan jenis konsumen secara berbeda-beda dan terpisah. Konsumen ini masing-masing memiliki karateristik, keinginan dan kebutuhan produk, serta bauran pemasarannya secara tersendiri. ${ }^{42}$ SMP Muhammadiyah 1 Depok Sleman melihat segmentasi pasar berdasarkan demografis (usia dan agama). SMP Muhammadiyah 1 Depok Sleman hanya menerima anak-anak peserta didik baru yang usianya 12 tahun dan yang beragama Islam. Sedangkan dari jenis kelamin, SMP Muhammadiyah 1 Depok Sleman menentukannya dengan cara membagi kelas tiap-tiap angkatannya dari kelas VII sampai kelas IX yaitu 4 kelas, jadi semua kelas yang ada di SMP Muhammadiyah 1 Depok Sleman adalah 12 kelas dari siswa-siswi yang dicampur dalam 1 kelas biasanya 30 anak. $^{43}$

Segmentasi kedua yang dilakukan SMP Muhammadiyah 1 Depok Sleman berdasarkan banyaknya peminat layanan pendidikan sekolah menengah pertama. Berdasarkan realitas dilapangan, terdapat banyak anak-anak di sekitar desa Maguwoharjo Depok Sleman. Dan ini yang menjadi target SMP Muhammadiyah 1 Depok Sleman dengan cara berbaur dan mendekati orang tua dan masyarakat di sekitar sekolah. ${ }^{44}$ Pada perkembangannya, SMP Muhammadiyah 1 Depok Sleman melihat banyak orang tua dari siswa yang sudah belajar di sekolah sibuk dalam bekerja, karena ada juga siswa-siswi dan kebanyakan dari kelas XI pergi ke sekolah dengan menggunakan jasa GOJEK maupun GRAB. Namun ketika pulang anak-anak dijemput kembali oleh orang tuanya, sebagaimana yang dijelaskan oleh Ibu Rini: "iya sekolah SMP Muhammadiyah 1 Depok Sleman ini anak saya lumayan bisa terjaga, karena disini dari shalat dhuha sampai shalat dhuhurnya berjamaah di musholla SMP, dan pulang biasanya setelah shalat ashar berjamaah, ini sangat membantu saya ketika sedang bekerja di luar". ${ }^{45}$

SMP Muhammadiyah 1 Depok Sleman membuka layanan fullday school. Layanan ini dimulai dari jam 07.00-15.00 WIB. Semua kegiatan yang dilakukan di sekolah sampai belajar, try out, shalat, istirahat dan bermain. Dari paparan tersebut

${ }^{42}$ Ara Hidayat dan Imam Machali, Pengelolaan Pendidikan (Konsep, Prinsip, dan Aplikasi dalam Mengelola Sekolah dan Madrasah), (Yogyakarta: Kaukaba, 2012), hlm. 224.

${ }^{43}$ Hasil wawancara dengan Pak Imron, Waka Kesiswaan SMP Muhammadiyah 1 Depok Sleman pada tanggal 29 Januari 2019, jam 09.00 - 10.00 WIB.

44 Observasi lapangan di SMP Muhammadiyah 1 Depok Sleman pada tanggal 25 Januari 2019, jam 09.00-10.00 WIB.

${ }^{45}$ Hasil wawancara dengan Ibu Rini, Wali murid SMP Muhammadiyah 1 Depok Sleman pada tanggal 29 Januari 2019, jam 13.35 - 14.05 WIB. 
ini sangat memudahkan orang tua siswa ketika sedang bekerja dengan anak-anak belajar di SMP Muhammadiyah 1 Depok Sleman.

\section{Targeting}

Targeting yaitu kegiatan dalam memilih satu, dua atau lebih segmen pasar yang menjadi target untuk dimasuki. ${ }^{46}$ Berdasarkan segmentasi yang dilakukan oleh SMP Muhammadiyah 1 Depok Sleman langkah selanjutnya adalah melakukan targeting. Sasaran pasar yang dituju SMP Muhammadiyah 1 Depok Sleman adalah anak-anak yang rentang usia 12 tahun dan yang beragama Islam. SMP Muhammadiyah 1 Depok Sleman mengakomodir siswa yang mendaftar dan mempunyai aturan tersendiri dalam penerimaan siswa baru.

Adapun aturan tersebut adalah yang pertama SMP Muhammadiyah 1 Depok Sleman telah membentuk tim PPDB (Penerimaan Peserta Didik Baru), seperti yang dijelaskan oleh Pak Imron: "iya kami membentuk tim PPDB terlebih dahulu, selanjutnya nanti siswa-siswa baru ini juga di interview, dan kami menetapkan jumlah pembayaran SPP masing-masing anak tergantung dengan background ekonomi orang tuanya masing-masing.," 47

Aturan yang kedua SMP Muhammadiyah 1 Depok Sleman mempunyai kuota siswa yang telah ditentukan. Ketika penerimaan peserta didik baru SMP Muhammadiyah 1 Depok Sleman menerima siswa baru 40 anak dalam setiap kelas, semua kelas yang dimiliki SMP Muhammadiyah 1 Depok Sleman berjumlah 12 kelas, masing-masing angkatan dibagi menjadi 4 kelas. ${ }^{48}$

\section{Positioning}

Positioning yaitu menetapkan dimana posisi pasar pemasar, hal ini dilakukan untuk mempertinggi nilai produk dan memberikan informasi tentang keunggulan produk yang dimiliki kepada para konsumen dan pelanggan. ${ }^{49}$ Berdasarkan observasi yang dilakukan peneliti, SMP dengan sistem fullday school cukup banyak. Dan SMP yang mengusung nilai-nilai Islam juga begitu banyak, namun untuk dapat berkompetisi dengan lembaga lainnya penetapan posisi pasar yang dilakukan SMP

${ }^{46}$ Ara Hidayat dan Imam Machali, Pengelolaan Pendidikan (Konsep, Prinsip, dan Aplikasi dalam Mengelola Sekolah dan Madrasah), (Yogyakarta: Kaukaba, 2012), hlm. 224.

${ }^{47}$ Hasil wawancara dengan Pak Imron, Waka Kesiswaan SMP Muhammadiyah 1 Depok Sleman pada tanggal 29 Januari 2019, jam 09.00 - 10.00 WIB.

48 Observasi lapangan di SMP Muhammadiyah 1 Depok Sleman pada tanggal 25 Januari 2019, jam 09.00-10.00 WIB.

${ }^{49}$ Ara Hidayat dan Imam Machali, Pengelolaan Pendidikan (Konsep, Prinsip, dan Aplikasi dalam Mengelola Sekolah dan Madrasah), (Yogyakarta: Kaukaba, 2012), hlm. 224. 
Muhammadiyah 1 Depok Sleman dibagi menjadi 2, yaitu sekolah yang berbasis pendidikan karakter dan jejaring atau networking. ${ }^{50}$

\section{Menetapkan Marketing Mix}

Dalam mengimplementasikan Strategi Pemasaran Jasa Pendidikan serta Peningkatan Pelayanan Pendidikan ada beberapa cara yang telah dilakukan, diantaranya:

\section{Marketing mix dan Peningkatan Pelayanan Pendidikan}

Bauran pemasaran (marketing mix) adalah alat-alat yang digunakan dalam menerapkan strategi pemasaran. Salah satu strategi pemasaran jasa pendidikan adalah melalui bauran pemasaran (marketing mix) yang terdiri dari 7P, yaitu product (produk): jasa seperti apakah yang akan ditawarkan oleh sekolah, price (harga): strategi penentuan harga yang bagaimana yang diterapkan sekolah, place (lokasi): dimana posisi dan letak tempat jasa pendidikan, promotion (promosi): bagaimana promosi yang dilakukan oleh sekolah agar pihak luar dan masyarakat luas banyak yang mengetahui terkait tentang sekolah, people (SDM): bagaimana kualitas, kualifikasi dan kompetensi yang terkait dalam pemberian jasa yang dimiliki sekolah, physical evidance (bukti fisik): sarana dan prasarana seperti apakah yang sudah dimiliki oleh sekolah, dan process (proses): manajemen layanan pendidikan dan unsur-unsur aktivitas yang unggul dari sekolah yang diberikan kepada siswa dan orang tua siswa, teori marketing mix ini digunakan karena teori ini sangatlah penting.

\section{a. Product (produk)}

Produk merupakan keseluruhan konsep objek atau proses yang memberikan sejumlah nilai kepada konsumen, yang penting untuk diperhatikan dalam produk adalah konsumen tidak hanya membeli fisik luar dari produk itu saja tapi juga membeli manfaat dan nilai dari produk tersebut. Sekolah yang mampu bertahan dan memenangkan persaingan jasa pendidikan adalah sekolah yang dapat menawarkan reputasi, layanan, prospek, mutu pendidikan yang baik, dan peluang yang cerah bagi lulusannya, serta mempunyai variasi pilihan konsentrasi bagi calon siswa yang sesuai dengan minat dan bakatnya.

Dalam hal produk SMP Muhammadiyah 1 Depok Sleman berusaha untuk meluluskan siswa yang unggul dan mampu meningkatkan produktivitas peserta didik dan ini dapat dilihat dengan peningkatan jumlah peserta didik meningkat tajam selama 3 tahun terakhir. Namun fokus produk SMP Muhammadiyah 1 Depok Sleman adalah dapat menghasilkan lulusan yang unggul dalam bidang intrakurikuler, keagamaan dan ekstrakurikuler.

${ }^{50}$ Hasil wawancara dengan Pak Abdullah Mukti, Kepala Sekolah SMP Muhammadiyah 1 Depok Sleman pada tanggal 23 Januari 2019, jam 10.00 - 11.30 WIB. 
Dalam bidang intrakurikuler SMP Muhammadiyah 1 Depok Sleman mempunyai prospek yang cukup optimis, yaitu (1) dari segi produktivitas sekolah dari waktu ke waktu kecenderungannya terus naik, bahkan naik tajam 3 tahun belakangan ini, dimulai dari tahun 2018 SMP Muhammadiyah 1 Depok Sleman sedang melakukan pembangunan gedung baru untuk lab IPA dan lab bahasa. (2) SDM sangat qualified $96 \%$ adalah guru-guru dan tenaga kerja muda. (3) latar belakang SDM yang sangat luar biasa yang tidak hanya basic dalam pengetahuannya saja tetapi juga mempunyai skill dalam pengembangan sekolah kedepannya, namun yang jadi prioritas sekolah adalah guru yang mengajar harus sesuai dengan kemampuan dan bidangnya masing-masing. Sehingga siswa dapat menerima ilmu dan memahaminya karena guru yang telah mengajar sesuai dengan bidangnya. ${ }^{51}$

SMP Muhammadiyah 1 Depok Sleman juga mempunyai kegiatankegiatan yang mendukung terbentuknya produk jasa pendidikan, seperti yang dijelaskan oleh Bapak Imron sebagai berikut: ${ }^{52}$ SMP Muhammadiyah 1 Depok Sleman memiliki tambahan kegiatan lainnya agar out put sekolah berbeda dengan sekolah lain. Sekolah mengadakan tambahan untuk mata pelajaran UN yaitu les UN untuk menunjang kemampuan siswa ketika menghadapi UN nanti, dan ini dimulai sejak kelas VIII jadwalnya pada hari senin dan selasa, dan kelas IX pada hari senin, selasa, rabu dan kamis 4 hari dengan mata pelajaran umum.

Peneliti juga mewawancarai seorang siswa yang baru saja mendapatkan mendali emas dalam perlombaan matematika se-tingkat provinsi DIY seangkatan SMP. Namanya Jibril: “ iya Alhamdulillah saya baru saja dapat medali emas dalam perlombaan matematika se-tingkat provinsi DIY seangkatan SMP yang diadakan di SMA 2 Muhammadiyah Yogyakarta pada januari 2019 kemarin. ${ }^{53}$ SMP Muhammadiyah 1 Depok Sleman juga sangat mengedepankan pembelajaran agama karena sekolah ini berbasis muhammadiyah, mata pelajaran Islam PAI agar out put sekolah berbeda dengan sekolah lain SMP Muhammadiyah 1 Depok Sleman mengadakan tambahan agama dengan nama jam ISMUBARIS. Jam ISMUBARIS berupa materi-materi tentang keislaman yang terdiri dari (1) penguatan doa-doa (2) hafalan juz 30 (3) hafalan ayat-ayat pilihan, kemudian penguatan ismubaris karena ris ini maksudnya adalah bahasa

\footnotetext{
${ }^{51}$ Hasil wawancara dengan Pak Abdullah Mukti, Kepala Sekolah SMP Muhammadiyah 1 Depok Sleman pada tanggal 23 Januari 2019, jam 10.00 - 11.30 WIB.

52 Hasil wawancara dengan Pak Imron, Waka Kesiswaan SMP Muhammadiyah 1 Depok Sleman pada tanggal 29 Januari 2019, jam 09.00 - 10.00 WIB.

${ }^{53}$ Hasil wawancara dengan Jibril, siswa SMP Muhammadiyah 1 Depok Sleman pada tanggal 29 Januari 2019, jam 12.30 - 13.00 WIB.
} 
arab dan bahasa inggris dengan mempelajari mufradat dan vocabularies dan kata-kata mutiara dari bahasa arab dan bahasa inggris. ${ }^{54}$

Selain produk yang dimiliki SMP Muhammadiyah 1 Depok Sleman tentang keagamaannya yang unggul, SMP Muhammadiyah 1 Depok Sleman juga mengedepankan produk non akademik yaitu olahraga dan ekstrakurikuler. ${ }^{55}$ Sebagaimana yang dikatakan oleh Bapak Abdullah Mukti: "karena visinya kita satu memiliki akhlak mulia kemudian cerdas berprestasi dan mandiri, ya jelas karakter akhlak mulia yang tadi kita jadi target utama ya sesuai dengan keislaman kemuhammmadiyahan. selanjutnya cerdas baik dalam segi akademik maupun non akademik dan kita selalu mendorong anak-anak agar bisa mencerdaskan mereka. Kalau ekstrakurikuler kelas VII dan VIII berjalan seperti biasa seperti pramuka, kepanduan, kelas VII wajib semuanya mengikuti kegiatan tapi kalau kelas VIII kita ambil beberapa kader pilihan inti saja untuk membimbing teman-teman yang lainnya ketika sedang latihan. ${ }^{56}$

Ekstrakurikuler di SMP Muhammadiyah 1 Depok Sleman ada yang wajib diikuti oleh siswa dan ada juga yang pilihan, yang wajib pertama yaitu kepramukaan dan yang wajib kedua yaitu tapak suci silat untuk membekali diri dan bisa melindungi orang lain, dan ekstrakurikuler pilihan ada banyak seperti drumband, bermain angklung dan olimpiade sains. ${ }^{57}$ Kegiatan ekstrakurikuler ini dilakukan di luar jam pelajaran biasa dan dilakukan baik di sekolah maupun di luar sekolah. Kegiatan ini berguna untuk memperluas pengetahuan siswa, menambah ketrampilan, mengenal hubungan antar berbagai mata pelajaran, serta tempat penyaluran bakat dan minat siswa.

Keunggulan dari SMP Muhammadiyah 1 Depok Sleman yang membedakan dengan sekolah-sekolah lain adalah ciri khas atau iconik dari sekolah. Sebagaimana yang dijelaskan oleh Bapak Abdullah Mukti: "yang menjadi ciri khas dan iconik di SMP Muhammadiyah 1 Depok Sleman yaitu ISMUBA, maksudnya sekolah memberikan kebiasaan keislaman dan kemuhammadiyahan sebagai bentuk karakter keislaman kepada peserta didik dan guru. Sekolah juga mengadakan pelatihan pedampingan intensif kepada

${ }^{54}$ Hasil wawancara dengan Pak Imron, Waka Kesiswaan SMP Muhammadiyah 1 Depok Sleman pada tanggal 29 Januari 2019, jam 09.00 - 10.00 WIB.

${ }^{55}$ Observasi lapangan di SMP Muhammadiyah 1 Depok Sleman pada tanggal 21 Mei 2018, jam 15.15-17.00 WIB.

${ }^{56}$ Hasil wawancara dengan Pak Abdullah Mukti, Kepala Sekolah SMP Muhammadiyah 1 Depok Sleman pada tanggal 23 Januari 2019, jam 10.00 - 11.30 WIB.

${ }^{57}$ Hasil wawancara dengan Pak Imron, Waka Kesiswaan SMP Muhammadiyah 1 Depok Sleman pada tanggal 29 Januari 2019, jam 09.00 - 10.00 WIB. 
guru dan karyawan bagaimana mengintegrasikan pendidikan karakter terhadap pembiasaan keislaman di SMP Muhammadiyah 1 Depok Sleman. ${ }^{58}$

Dengan itu maka sekolah mengedepankan pendidikan karakter kepada guru dan karyawan terlebih dahulu sehingga diintegrasikan kepada peserta didik. Dengan keunggulan-keunggulan yang dimiliki oleh SMP Muhammadiyah 1 Depok Sleman dapat digunakan sebagai alat untuk memenangkan persaingan dan mempunyai ciri khas serta membedakan dari sekolah-sekolah lainnya.

\section{b. Price (harga)}

Harga dalam pemasaran adalah jumlah uang yang harus dibayarkan oleh stakeholder dan konsumen untuk memperoleh suatu produk. Harga dalam konteks jasa pendidikan adalah seluruh biaya yang dikeluarkan oleh konsumen untuk mendapatkan jasa pendidikan yang telah ditawarkan. ${ }^{59}$ Harga yang ditawarkan SMP Muhammadiyah 1 Depok Sleman masih sangat terjangkau dan tidak terlalu mahal dibandingkan dengan sekolah-sekolah lain yang setara.

Seperti yang dijelaskan oleh bapak Abdullah Mukti: "ya di SMP Muhammadiyah 1 Depok Sleman kalau tentang SPP nya tidak terlalu mahal ya dan termasuk murah juga dibandingkan dengan sekolah-sekolah lain yang setara, untuk tahun ajaran 2018/2019 itu paling murah biaya SPP nya 125 ribu, selanjutnya ada juga yang 150 dan yang paling tinggi 175 ribu tergantung kemampuan background ekonomi dari orang tua siswanya". ${ }^{60}$

Selain itu, SMP Muhammadiyah 1 Depok Sleman mendapat dana tambahan Bantuan Operasional Sekolah (BOS) dari Kementerian Pendidikan yang dipergunakan untuk sarana prasarana sekolah. ${ }^{61}$ Jadi uang komite itu adalah uang pembayaran sekolah dalam satu tahun ajaran dan dalam penentuan besar jumlahnya maka pihak sekolah melakukan musyawarah dengan orang tua siswa terlebih dahulu. Seperti yang dijelaskan oleh Ibu Sri Mulyati selaku orang tua siswa kelas IX: "iya kalau di SMP Muhammadiyah 1 Depok Sleman ini masalah SPP nya pihak sekolah bermusyawarah dahulu dengan kami selaku orang tua siswa sebelum menetapkan harga SPP-nya, kebetulan saya kena SPP

${ }^{58}$ Hasil wawancara dengan Pak Abdullah Mukti, Kepala Sekolah SMP Muhammadiyah 1 Depok Sleman pada tanggal 23 Januari 2019, jam 10.00 - 11.30 WIB.

${ }^{59}$ Ara Hidayat dan Imam Machali, Pengelolaan Pendidikan, (Yogyakarta: Kaukaba, 2012), hlm. 239.

${ }^{60}$ Hasil wawancara dengan Pak Abdullah Mukti, Kepala Sekolah SMP Muhammadiyah 1 Depok Sleman pada tanggal 23 Januari 2019, jam 10.00 - 11.30 WIB.

${ }^{61}$ Hasil wawancara dengan Pak Imron, Waka Kesiswaan SMP Muhammadiyah 1 Depok Sleman pada tanggal 29 Januari 2019, jam 09.00 - 10.00 WIB. 
nya 125 ribu per-bulan, ada juga yang 150 ribu sampai yang tertinggi 175 ribu per-bulan. ${ }^{62}$

Namun di sisi lain SMP Muhammadiyah 1 Depok Sleman juga memberikan beasiswa kepada siswa yang berprestasi dan siswa yang kurang mampu yaitu yatim piatu. "Alhamdulillah saya sekolah di SMP Muhammadiyah 1 Depok Sleman ini dari kelas VII sampai kelas IX nanti beasiswa terus, karena saya mendapatkan beasiswa berprestasi dan itu di seleksi dulu oleh pihak sekolah dan diwawancarai langsung oleh Bapak Abdullah Mukti, namun ada juga siswa yang mendapatkan beasiswa bagi siswa-siswa yang tidak mampu ataupun anak yang yatim piatu."63

Tujuan dari pemberian beasiswa ini untuk meningkatkan motivasi belajar siswa dan apresiasi bagi siswa yang berprestasi agar tetap rajin dan konsisten. Pemberian beasiswa ini berdasarkan siswa yang berprestasi dan kurang mampu, dana beasiswa ini salah satunya diperoleh dari PIP yaitu Program Indonesia Pintar. Seperti yang dijelaskan oleh Bapak Imron selaku Waka bagian kesiswaan: "iya sekolah memberikan beasiswa seperti PIP (Program Indonesia Pintar) namun telah dikhususkan kepada siswa yang kurang mampu dan berprestasi. ${ }^{64}$ Untuk siswa penerima beasiswa PIP biasanya setiap tahun mendapatkan jatah sekitar 100 siswa, meskipun dari pihak sekolah mengajukan lebih akan tetapi sudah ditetapkan jumlahnya dari pemerintah. Selain dana dari PIP ada juga dana lain untuk beasiswa yang diterima oleh SMP Muhammadiyah 1 Depok Sleman, yaitu: (1) dana prestasi, (2) bantuan operasional sekolah (BOS), (3) bantuan dari dinas sosial Sleman.

Meski SPP di SMP Muhammadiyah 1 Depok Sleman termasuk murah dibandingkan dengan sekolah lain yang setara namun ini tidak berpengaruh terhadap kualitas yang dimiliki oleh sekolah. Dengan harga murah tersebut kualitas tetap terjaga, maka banyak orang tua yang menyekolahkan anaknya ke sekolah ini, hal tersebut membuat konsumen semakin tertarik untuk menikmati pelayanan yang diberikan oleh SMP Muhammadiyah 1 Depok Sleman. ${ }^{65}$

\section{c. Place (Lokasi)}

Dalam konteks jasa pendidikan place merupakan lokasi lembaga sekolah berada. Lokasi sekolah sedikit banyak memang akan menjadi sebuah pilihan,

${ }^{62}$ Hasil wawancara dengan Ibu Sri Mulyati, Wali murid SMP Muhammadiyah 1 Depok Sleman pada tanggal 29 Januari 2019, jam 13.10 - 13.30 WIB.

${ }^{63}$ Hasil wawancara dengan Jibril, siswa SMP Muhammadiyah 1 Depok Sleman pada tanggal 29 Januari 2019, jam 12.30 - 13.00 WIB.

${ }^{64}$ Hasil wawancara dengan Pak Imron, Waka Kesiswaan SMP Muhammadiyah 1 Depok Sleman pada tanggal 29 Januari 2019, jam 09.00 - 10.00 WIB.

65 Observasi lapangan di SMP Muhammadiyah 1 Depok Sleman pada tanggal 21 Mei 2018, jam 15.15-17.00 WIB. 
kenyamanan dan kemudahannya ketika dijangkau akan menjadi daya tarik khusus bagi masyarakat, dibandingkan dengan lokasi sekolah yang terletak di dekat pasar, pemakaman dan lain-lain. ${ }^{66}$ Lokasi yang strategis menjadi daya tarik sendiri dan menjadi preferensi untuk pengambilan keputusan dari perilaku konsumen.

Lokasi SMP Muhammadiyah 1 Depok Sleman terletak di dusun Stan, Desa Maguwoharjo, Kecamatan Depok, Kabupaten Sleman, Provinsi Daerah Istimewa Yogyakarta. Kondisi SMP Muhammadiyah 1 Depok Sleman berada di tengah-tengah dusun Stan, maka dari itu letaknya cukup strategis untuk dijangkau transportasi umum tetapi mudah juga dijangkau dengan kendaraan pribadi. ${ }^{67}$ Posisi SMP Muhammadiyah 1 Depok Sleman masuk ke dalam tidak tepat di pinggir jalan raya, maka dari itu suasananya cozy karena jauh dari polusi asap kendaraan, bising kendaraan, ataupun keramaian jalan, sehingga anak-anak sangat nyaman untuk belajar.

Selain memiliki letak yang cukup startegis, SMP Muhammadiyah 1 Depok Sleman juga mempunyai lahan parkir yang cukup memadai untuk karyawan dan guru. Karena sekolah sekarang sedang merenovasi gedung dan pembangunan gedung baru untuk ruang guru dan lab IPA maka kondisi lahan parkir sedikit terganggu, namun setelah pembangunan selesai nanti lahan parkir akan kembali teratur. ${ }^{68}$ Lokasi SMP Muhammadiyah 1 Depok Sleman yang cukup strategis dan suasana yang sangat kondusif dapat mempengaruhi minat dan ketertarikan dari konsumen orang tua siswa untuk menyekolahkan anaknya di SMP Muhammadiyah 1 Depok Sleman Yogyakarta.

\section{d. Promotion (promosi)}

Promosi adalah aktivitas dalam melakukan komunikasi penjualan produk di pasaran yang secara langsung berhubungan dengan masyarakat. Promosi bertujuan untuk memberikan informasi serta meyakinkan konsumen atau masyarakat akan manfaat dan nilai dari produk yang dihasilkan. Kegiatan promosi yang bisa dilakukan melalui advertising (iklan), televisi, radio, surat kabar, surat harian, bulletin, spanduk, majalah, brosur, baliho dan lain-lain. Promosi penjualan juga dapat dilakukan seperti adanya pameran pendidikan, bazar pendidikan dan invitasi. Hal lain yang bisa dilakukan adalah melakukan

\footnotetext{
${ }^{66}$ Ara Hidayat dan Imam Machali, Pengelolaan Pendidikan...., hlm. 239.

${ }^{67}$ Observasi lapangan di SMP Muhammadiyah 1 Depok Sleman pada tanggal 21 Mei 2018, jam 15.15-17.00 WIB.

${ }^{68}$ Hasil wawancara dengan Pak Abdullah Mukti, Kepala Sekolah SMP Muhammadiyah 1 Depok Sleman pada tanggal 23 Januari 2019, jam 10.00 - 11.30 WIB.
} 
kontak langsung dengan calon siswa dan orang tua siswa serta melakukan kegiatan hubungan baik dan positif dengan masyarakat. ${ }^{69}$

Kegiatan promosi yang dilakukan di SMP Muhammadiyah 1 Depok Sleman menggunakan 3 cara yaitu yang pertama, promosi secara langsung dengan menggunakan brosur, website sekolah dan koran suara muhammadiyah. Seperti yang dijelaskan oleh Bapak Abdullah Mukti: "kegiatan promosi yang pertama dengan memanfaatkan media informasi dan sosial karena komunikasi yang sangat menarik adalah media. Seperti kegiatan sekolah yang keluar di koran suara muhammadiyah dan berbagai event sekolah juga berusaha untuk ikut partisipasi. Sekolah juga membuat brosur, spanduk, kalender dan lain-lain. ${ }^{70}$

Kedua, menggunakan public relations. Untuk mempromosikan sekolahnya SMP Muhammadiyah 1 Depok Sleman mengadakan kegiatan untuk menarik warga sekitar. Kegiatan tersebut seperti diadakannya acara kurban yang dilakukan oleh anak-anak dan melibatkan masyarakat, dengan demikian warga menjadi tertarik terhadap sekolah dengan adanya kegiatan-kegiatan seperti ini. Ketiga, word of mouth. Maksudnya adalah pelanggan SMP Muhammadiyah 1 Depok Sleman menceritakan pengalaman menyekolahkan anaknya kepada teman-teman atau tetangganya. Namun disini dibutukan pelayanan yang berkualitas agar kepuasan pelanggan yang dirasakan membuat mereka dengan sendirinya mempromosikan SMP Muhammadiyah 1 Depok Sleman. ${ }^{71}$

Menurut Bapak Abdullah Mukti: "all everything is promot, segala hal yang kita lakukan adalah promosi. Seperti pelayanan yang kita berikan kepada siswa dan orang tua disini punya prinsip service is excellent maka ketika kita bisa memberikan pelayanan yang baik kepada user kepada siswa dan orang tua harapannya bisa berimbas kepada promosi sekolah. ${ }^{72}$

Sedangkan promosi menurut Bapak Sudarsono: promosi sekolah dilakukan melalui (1) ranting muhammadiyah dan cabang (2) kepada tokohtokoh masyarakat sekitar (3) mempromosikan SMP Muhammadiyah 1 Depok Sleman dengan sekolah-sekolah dasar yang ada di wilayah Depok, kecamatan Kalasan maupun kecamatan Ngemplak. Selain itu sekolah mengadakan event-

\footnotetext{
${ }^{69}$ Ara Hidayat dan Imam Machali, Pengelolaan Pendidikan...., hlm. 239.

${ }^{70}$ Hasil wawancara dengan Pak Abdullah Mukti, Kepala Sekolah SMP Muhammadiyah 1 Depok Sleman pada tanggal 23 Januari 2019, jam 10.00 - 11.30 WIB.

${ }^{71}$ Hasil wawancara dengan Pak Imron, Waka Kesiswaan SMP Muhammadiyah 1 Depok Sleman pada tanggal 29 Januari 2019, jam 09.00 - 10.00 WIB.

${ }^{72}$ Hasil wawancara dengan Pak Abdullah Mukti, Kepala Sekolah SMP Muhammadiyah 1 Depok Sleman pada tanggal 23 Januari 2019, jam 10.00 - 11.30 WIB.
} 
event pekan olahraga seperti diadakannya turnamen futsall, try out dan juga lomba-lomba yang pesertanya dari tingkat SD kelas 4,5 dan $6 .^{73}$

Dari uraian di atas dapat disimpulkan bahwa promosi adalah kegiatan untuk mengenalkan lembaga pendidikan kepada masyarakat sebagai alat untuk mempengaruhi konsumen atau masyarakat agar tertarik dalam menggunakan jasa pendidikan sesuai keinginan dengan mengedepankan mutu pendidikan. Namun upaya promosi yang dilakukan SMP Muhammadiyah 1 Depok Sleman untuk lebih dikenal oleh masyarakat adalah dengan mengedepankan nilai-nilai agama kemuhammadiyahan. Selain SMP Muhammadiyah 1 Depok Sleman mempunyai guru-guru muda yang cekatan dan cepat dalam bekerja juga mempunyai tanggung jawab untuk menarik para calon siswa. ${ }^{74}$ Jadi nantinya yang akan disampaikan oleh masyarakat adalah bidang keagamaannya, seperti shalat berjamaah dari shalat dhuha, shalat dhuhur dan shalat ashar di mosholla sekolah. Disamping itu ada juga program buta huruf al-Qur'an seperti istilah iqra', dengan demikian masyarakat lebih mengenal dan mengetahui program keunggulan sekolah dari bidang keagamaan. ${ }^{75}$

Dalam pelaksanaan promosi pihak sekolah juga mengalami beberapa kendala, seperti yang dijelaskan oleh Bapak Imron: "biasanya untuk kendalanya kita berebut dimana mencari siswa yang mendaftar dengan sekolah-sekolah swasta yang lain. Biasanya itu persaingannya dengan MTSN Maguwoharjo dan Ngemplak. Jadi kita mengirim guru-guru kita untuk mensosiasikan siswa-siswa dan mendekati orang tua, target utama kita itu ya SD Muhammadiyah Sapen dan SD Muhammadiyah Condongcatur karena anak-anak disana lebih unggulunggul. ${ }^{76}$ Kegiatan promosi yang dilakukan untuk mengenalkan sekolah kepada masyarakat atau konsumen tetap mengedepankan nilai-nilai agama, dan SMP Muhammadiyah 1 Depok Sleman sudah melakukan promosi dengan secara maksimal walaupun memiliki sedikit kendala tetapi tidak berpengaruh terhadap pelaksanaannya.

\section{e. People (SDM)}

Dalam proses pemasaran jasa pendidikan yang dilakukan orang-orang yang bertugas sebagai penyedia jasa sangat berpengaruh terhadap kualitas jasa yang akan diberikan. Dalam kegiatan ini orang-orang yang terlibat dalam menyampaikan jasa pendidikan adalah guru dan karyawan yang dimiliki oleh

${ }^{73}$ Hasil wawancara dengan Pak Sudarsono, Waka Humas SMP Muhammadiyah 1 Depok Sleman pada tanggal 29 Januari 2019, jam 10.10 - 10.50 WIB.

${ }^{74}$ Observasi lapangan di SMP Muhammadiyah 1 Depok Sleman pada tanggal 21 Mei 2018, jam 15.15-17.00 WIB.

${ }^{75}$ Hasil wawancara dengan Pak Sudarsono, Waka Humas SMP Muhammadiyah 1 Depok Sleman pada tanggal 29 Januari 2019, jam 10.10 - 10.50 WIB.

${ }^{76}$ Hasil wawancara dengan Pak Imron, Waka Kesiswaan SMP Muhammadiyah 1 Depok Sleman pada tanggal 29 Januari 2019, jam 09.00 - 10.00 WIB. 
sekolah. Maka dari itu sumber daya pendidik dan tenaga kependidikan sangatlah penting karena ini menjadi tolak ukur dan ujung tombak dalam melakukan proses pemberian layanan pendidikan kepada para peserta didik. ${ }^{77}$

Guru-guru dan karyawan di SMP Muhammadiyah 1 Depok Sleman memiliki standar kompetensi yang hampir sama dengan sekolah lainnya, namun di SMP Muhammadiyah 1 Depok Sleman lebih menekankan komitmen loyalitas yang tinggi bagi guru dan karyawan. Sebagaimana yang dijelaskan oleh Bapak Abdullah Mukti: “di SMP kita juga menggunakan 8 standar SNP, tapi kemudian yang paling kita kuatkan disini biasanya orang yang berfikir profesional dan kita lebih mendorong komitmen loyalitas dulu kepada calon-calon guru muda karena SMP Muhammadiyah 1 Depok Sleman kita punya misi khusus dan ciri khusus." $" 78$

Dalam proses perekrutan guru dan karyawan di SMP Muhammadiyah 1 Depok Sleman menggunakan sistem seleksi. Sistem seleksi yang dilakukan oleh SMP Muhammadiyah 1 Depok Sleman juga sangat ketat karena sekolah mempunyai standar khusus yang tidak hanya nilai coumlade tetapi SDM juga harus kuat dan mempunyai dedikasi yang tinggi. Seperti yang dijelaskan oleh Bapak Abdullah Mukti: "guru-guru disini kita seleksi bukan hanya yang mempunyai nilai coumlade tetapi juga yang mempunyai dedikasi yang tinggi, secara kita punya 2 mekanisme seleksi yang pertama itu tidak dengan seleksi khusus tapi kita melihat mahasiswa-mahasiswa yang mempunyai skill dan mampu dalam mengajar iqro', juga kita melihat yang PPL disini kalau memang dia mampu biasanya ya kita minta dan juga kita melihat apakah dia punya background aktivis di organisasinya dan memiliki kompetensi. Yang kedua dengan tes khusus dan disini kita melibatkan tidak hanya sekolah tetapi juga persyarikatan dari pihak muhammadiyah dan seleksi tesnya selama 2 hari, hari pertama kita tes terkait dengan kepribadian individu dan loyalitas tentang keagamaan baik itu ngajinya, shalatnya dan wawasan kemuhammadiyahannya menjadi syarat muthlak lulus, dan ini tidak hanya untuk guru agama saja, guru non agama juga kami seleksi seperti ini juga. Makanya kenapa ISMUBARIS yang mengelola tidak hanya dari guru agama karena memang dari sejak awal kita seleksinya juga sama antara guru agama maupun guru non agama yaitu guru-guru eksat. Selanjutnya hari yang kedua terkait tentang praktik mengajar bagaimana strategi mengajar dan yang paling penting di kita dia itu punya loyalitas dan dedikasi yang tinggi. ${ }^{79}$

\footnotetext{
${ }^{77}$ Ara Hidayat dan Imam Machali, Pengelolaan Pendidikan...., hlm. 240.

${ }^{78}$ Hasil wawancara dengan Pak Abdullah Mukti, Kepala Sekolah SMP Muhammadiyah 1 Depok Sleman pada tanggal 23 Januari 2019, jam 10.00 - 11.30 WIB.

${ }^{79}$ Ibid.
} 
Untuk meningkatkan kompetensi guru dan karyawan SMP Muhammadiyah 1 Depok Sleman mengadakan pelatihan-pelatihan seperti pelatihan workshop untuk pengembangan kemampuan guru-guru, mengikuti seminar-seminar yang menunjang kompetensi guru sekolah dan ini sangatlah mendukung. Sedangkan untuk karyawan-karyawan di SMP Muhammadiyah 1 Depok Sleman dalam meningkatkan kompetensi maka mereka ditrainingkan agar karyawan dapat menambah wawasan dan mampu mengelola sesuai dengan bidangnya masing-masing. ${ }^{80}$

Dalam proses belajar mengajar di SMP Muhammadiyah 1 Depok Sleman guru-guru yang mengajar sesuai dengan kemampuan dan skill bidang yang diampunya. Hal ini berguna untuk proses pembelajaran yang baik dan efektif karena tidak ada guru yang mengampu lebih dari satu mata pelajaran, setiap guru hanya boleh mengampu satu mata pelajaran yang memang benar guru tersebut sudah ahli dan mampu menguasai pelajaran yang diampunya.

SMP Muhammadiyah 1 Depok Sleman berstatus sebagai sekolah swasta dan dinaungi oleh yayasan muhammadiyah maka mempunyai kewenangan khusus dalam menyeleksi guru-guru sesuai dengan kader kemuhammadiyahan. Dengan kualitas SDM yang dimiliki SMP Muhammadiyah 1 Depok Sleman ini maka dapat dijadikan sebagai peningkatan pelayanan pendidikan sekolah sehingga konsumen semakin tertarik untuk menikmati pelayanan yang diberikan oleh SMP Muhammadiyah 1 Depok Sleman.

\section{f. Physical evidence (bukti fisik)}

Sarana fisik yang dimiliki oleh suatu lembaga pendidikan juga menjadi hal yang perlu diperhatikan karena ini menjadi pengaruh terhadap keputusan konsumen untuk membeli dan memakai produk jasa yang diberikan.. ${ }^{81}$ Physical evidence (bukti fisik) adalah lingkungan fisik tempat jasa diciptakan dan langsung berinteraksi dengan pelanggannya. Bukti fisik merupakan bukti penting yaitu keputusan-keputusan yang dibuat oleh pemberi jasa mengenai desain dan bangunan fisik, sarana prasarana, perlengkapan, logo lembaga, warna lembaga dan lain sebagainya. ${ }^{82}$ Sarana prasarana merupakan faktor penting yang mendukung dan menunjang proses pembelajaran di sekolah, oleh karena itu fasilitas dan sarana prasarana mempunyai pengaruh yang sangat penting. Di SMP Muhammadiyah 1 Depok Sleman sarana dan prasarana sudah cukup memadai. Berikut adalah fasilitas yang dimiliki oleh SMP Muhammadiyah 1 Depok Sleman: (a) ruang kelas yang menggunakan AC untuk kelas IX, kelas VII dan VIII masih menggunakan kipas angin, namun ruang kelas yang memadai,

\footnotetext{
${ }^{80}$ Ibid.

${ }^{81}$ Buchari Alma dan Ratih Huriyati, Manajemen Corporate..., hlm. 166.

${ }^{82}$ Ara Hidayat dan Imam Machali, Pengelolaan Pendidikan...., hlm. 240.
} 
tenang, aman dan nyaman dengan papan tulis white board, (b) musholla yang memadai dan cukup luas, (c) laboratorium IPA, (d) laboratorium komputer yang dilengkapi dengan wifi, (e) ruang ketrampilan, (f) perpustakaan dengan ruang baca yang representatif, (g) lapangan olahraga, bola basket, bola voli dan peralatan senam, (h) kantin. ${ }^{83}$

Dari sarana prasarana yang dimiliki oleh SMP Muhammadiyah 1 Depok Sleman sudah mampu dalam memenuhi standar sekolah dan mampu menunjang proses belajar mengajar. Hal ini dapat dilakukan sebagai alat dalam pemasaran jasa pendidikan agar orang tua siswa tertarik untuk menyekolahkan anaknya di SMP Muhammadiyah 1 Depok Sleman.

\section{g. Process (proses)}

Proses merupakan seluruh prosedur aktual, mekanisme serta aliran aktivitas yang dipakai dalam menyampaikan suatu jasa. ${ }^{84}$ Proses merupakan gabungan dari seluruh aktivitas yang umumnya terdiri atas prosedur-prosedur, jadwal pekerjaan, serta hal-hal rutin yang dilakukan. Dalam kontek jasa pendidikan yang dimaksud dengan proses adalah proses pendidikan yang mendukung terselenggaranya seluruh proses kegiatan belajar-mengajar yang terdiri dari segala unsur-unsur kegiatan untuk terciptanya produk atau lulusan yang diharapkan. ${ }^{85}$

Proses merupakan hal yang penting dalam penyampaian jasa pendidikan. Konsumen dan pelanggan akan merasakan sistem yang ada dalam proses tersebut. Proses penyampaian jasa dari produsen ke konsumen harus diperhatikan secara baik. Hal ini dikarenakan proses pembelajaran merupakan produk utama dan sakral dalam pemasaran jasa pendidikan. Agar terlaksana proses pembelajaran yang efektif dan efesien SMP Muhammadiyah 1 Depok Sleman mencoba menfasilitasi siswa dengan berbagai macam kegiatan belajar mengajar (KBM), fasilitas sarana prasarana yang memadai dan kegiatan ekstrakurikuler. Semua kegiatan tersebut berperan penting dalam menunjang dan mempertinggi nilai dan proses pembelajaran yang dapat meningkatkan minat pendaftar. $^{86}$

Kegiatan yang mendukung terselenggaranya proses belajar mengajar yang bertujuan untuk membentuk produk lulusan di SMP Muhammadiyah 1

${ }^{83}$ Observasi lapangan di SMP Muhammadiyah 1 Depok Sleman pada tanggal 21 Mei 2018, jam 15.15-17.00 WIB.

${ }^{84}$ Buchori Alma \& Ratih hurriyati, Manajemen Corporate Strategi \& Pemasaran Jasa Pendidikan (Bandung: Alfabeta, 2008), hlm. 166.

${ }^{85}$ Ara Hidayat dan Imam Machali, Pengelolaan Pendidikan, Konsep, Prinsip, Dan Aplikasi Dalam Mengelola Sekolah Dan Madrasah (Yogyakarta: Penerbit Kaukaba, 2012), hlm. 241.

${ }^{86}$ Hasil wawancara dengan Pak Abdullah Mukti, Kepala Sekolah SMP Muhammadiyah 1 Depok Sleman pada tanggal 23 Januari 2019, jam 10.00 - 11.30 WIB. 
Depok Sleman yang diharapkan maka disesuaikan dengan KBM pada kurikulum. Sedangkan kurikulum yang mengatur proses kegiatan belajar mengajar sudah diatur dan ditetapkan dalam perundang-undangan. SMP Muhammadiyah 1 Depok Sleman sudah menggunakan kurikulum 2013. ${ }^{87}$

Data agregat siswa dari tahun 2008-2019 menunjukkan keberhasilan implementasi strategi pemasaran jasa pendidikan di SMP Muhammadiyah 1 Depok Sleman, pada tahun 2008 kelas VII hanya 8 siswa dan keseluruhannya 67 siswa, tahun 2009 SMP Muhammadiyah 1 Depok memiliki 99 siswa, tahun 2010 yaitu 106 siswa, tahun 2011 yaitu 143 siswa, tahun 2012 yaitu 216 siswa, tahun 2013 yaitu 256 siswa, tahun 2014 yaitu 348 siswa, tahun 2015 yaitu 383 siswa, tahun 2016 yaitu 391 siswa, tahun 2017 yaitu 384 siswa dan pada tahun 2018 yaitu 326 siswa. ${ }^{88}$ Perbandingan dilakukan pada tahun 2008 dimana SMP Muhammadiyah 1 Depok Sleman hanya memiliki 67 siswa.

\section{KESIMPULAN}

Implementasi strategi pemasaran jasa pendidikan SMP Muhammadiyah 1 Depok Yogyakarta sebagai berikut: (a) Melakukan strategi pemilihan pasar yaitu dengan melakukan segmentasi pasar, targeting dan positioning. (b) Menetapkan marketing mix agar dapat meningkatkan pelayanan pendidikan di SMP ini dengan cara menerapkan produk-produk yang berkualitas, fokus produk SMP Muhammadiyah 1 Depok Sleman adalah dapat menghasilkan lulusan yang unggul dalam bidang intrakurikuler, keagamaan dan ekstrakurikuler.

Produk lain yang dimiliki SMP Muhammadiyah 1 Depok Sleman yaitu ISMUBA, sekolah memberikan kebiasaan keislaman dan kemuhammadiyahan sebagai bentuk karakter keislaman kepada peserta didik dan guru. Sekolah juga mengadakan pelatihan pedampingan intensif kepada guru dan karyawan bagaimana mengintegrasikan pendidikan karakter terhadap pembiasaan keislaman di SMP Muhammadiyah 1 Depok Sleman. Menetapkan jasa pendidikan yang lebih murah dibandingkan dengan sekolah lain yang setara namun tidak berpengaruh terhadap kualitas yang dimiliki oleh sekolah dan ini terbukti banyak orang tua yang menyekolahkan anaknya ke sekolah ini. Menonjolkan letak geografis SMP Muhammadiyah 1 Depok Sleman yang cukup strategis guna mempermudah akses calon pengguna jasa pendidikan.

Melakukan strategi promosi dengan cara advertising (iklan) melalui media $\mathrm{TV}$, radio, surat kabar, bulletin, majalah, baliho, brosur dan lain-lain. Menonjolkan SDM dengan menyeleksi guru-guru sesuai dengan kader kemuhammadiyahan. Menunjukkan bukti fisik sekolah agar konsumen yakin dengan proses pembelajaran

${ }^{87}$ Ibid.

${ }^{88}$ Hasil dokumentasi yang peneliti lakukan di SMP Muhammadiyah 1 Depok dengan Bapak Abidin selaku Waka Kurikulum pada 29 Januari 2019 pukul 09.00 WIB. 
di SMP Muhammadiyah 1 Depok Sleman, bukti fisik yang dimiliki SMP ini seperti ruang kelas yang menggunakan AC untuk kelas IX, kelas VII dan VIII masih menggunakan kipas angin, namun ruang kelas yang memadai, tenang, aman dan nyaman dengan papan tulis white board. Dari Physical evidence (bukti fisik) yang dimiliki oleh SMP Muhammadiyah 1 Depok Sleman sudah mampu memenuhi standar sekolah dan mampu menunjang proses belajar mengajar. Melakukan proses sebagai bentuk untuk meningkatkan produk lulusan yang disesuaikan dengan KBM pada kurikulum.

\section{DAFTAR PUSTAKA}

Alma, Buchari, Manajemen Corporate \& Pemasaran Jasa Pendidikan, Bandung: Alfabeta, 2008.

Alma, Buchari, \& Ratih hurriyati, Manajemen Corporate Strategi \& Pemasaran Jasa Pendidikan, Bandung: Alfabeta, 2008.

Barata, Atep Adya, Dasar-Dasar Pelayanan Prima, Jakarta: Elex Media Kompetido, 2003.

Engkoswara \& Komariah, Aan, Administrasi Pendidikan, Bandung: Alfabeta, 2010.

Gerard J. Tellis, et. al., "Radical Innovation Across Nations: The Preeminence of Corporate Culture", Journal of Marketing, vol. 73 (2009).

Hamruni, Edutainment Dalam Pendidikan Islam dan Teori-Teori pembelajaran Quantum, Yogyakarta: Fakultas Tarbiyah UIN Sunan Kalijaga, 2009.

Hidayat, Ara dan Machali, Imam, Pengelolaan Pendidikan, Konsep, Prinsip, Dan Aplikasi Dalam Mengelola Sekolah Dan Madrasah, Yogyakarta: Penerbit Kaukaba, 2012.

Kotler, Philip, Manajemen pemasaran: analisis, perencanaan, implementasi, dan pengendalian Jilid 2 Edisi 8, (terj.) oleh. A.B. Susanto, Jakarta: Salemba Empat, 1995.

Lupiyoadi, Rambat \& A.Hamdani, Manajemen Pemasaran Jasa, Jakarta: Salemba Empat, 2006.

Muhaimin, Manajemen Pendidikan (Aplikasinya dalam Penyusunan Rencana Pengembangan Sekolah/Madrasah),cet.4, Jakarta: Kencana prenada Media Group, 2009.

Muhammad Arham, "Islamic Perspective on Marketing", Journal of Islamic Marketing, vol. 1, no. 2. 
Nizar, Ali dan Ali Syatibi, Manajemen Pendidikan Islam, Bekasi: Pustaka Isfahan, 2009.

Perreault, Cannon, McCarthy, Pemasaran Dasar Pendekatan Manajerial Global, (terj.) oleh. Diana Angelica, Jakarta: Salemba 4, 2008.

Sugiyono, Metode Penelitian Kuantitatif, Kualitatif dan $R \& D$, Bandung: Alfabeta, 2013.

Sugiyono. Metode Penelitian Pendidikan, Bandung: Alfabeta, 2012.

Syamsuddin \& Vismania, Metode Penelitian Pendidikan Bahasa, Bandung: PT. Remaja Rosdakarya, 2007.

Tjiptono, Fandy, Pemasaran Jasa, Yogyakarta: Penerbit Andi, 2014.

Wijaya, David, Pemasaran Jasa Pendidikan: Mengapa Sekolah Memerlukan Marketing?, Jakarta: Salemba Empat, 2012.

Wilson, J. A. J. (2012), "Looking at Islamic marketing, branding and Muslim consumer behavior beyond the 7P's", Journal of Islamic Marketing, Vol. 3, hlm. 212-216. 